DOI: https://doi.org/10.31933/dijdbm.v2i1

Received: 5 October 2020, Revised: 15 November 2020, Publish: 10 December 2020

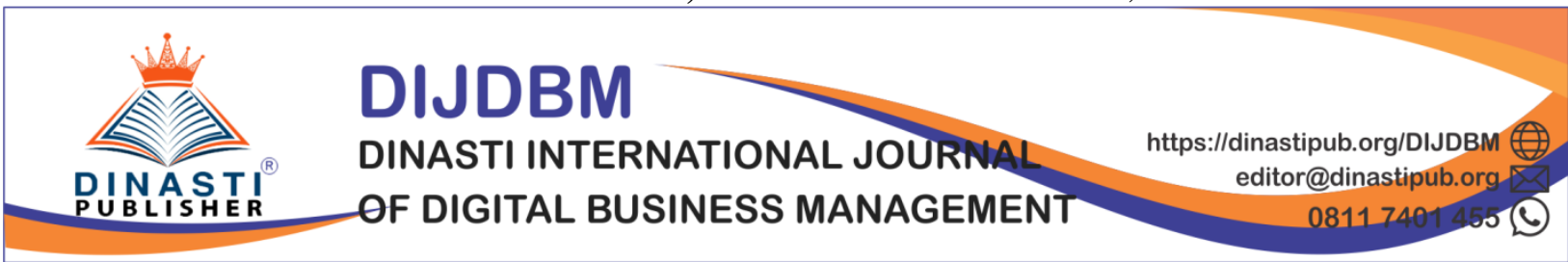

\title{
KOMA THEATER'S MARKETING THROUGH SOCIAL MEDIA CASE STUDY: 'GEMINTANG' SHOW
}

\author{
Dhiaz Danastri' ${ }^{1}$, Putri Dwirizky ${ }^{2}$, Tonie Kurniawan ${ }^{3}$ \\ ${ }^{1)}$ Institut Komunikasi dan Bisnis LSPR, Jakarta, dhiazd@gmail.com \\ ${ }^{2)}$ Institut Komunikasi dan Bisnis LSPR, Jakarta, putridwirizky2210@ gmail.com \\ ${ }^{1)}$ Institut Komunikasi dan Bisnis LSPR, Jakarta, kurtonie@ gmail.com
}

Coresponding Author: Dhiaz Danastri

\begin{abstract}
For around 41 years, Theater Koma did not stop working. Continued to produce until its name is increasingly known, then holds a special place in the hearts of its fans. It's not an easy thing to maintain a theater community which in Indonesia is not yet popular. As the times changed, slowly but surely, Theater Koma's audience entered a period of regeneration. Performing arts production requires proper marketing techniques so the show could be accepted by the target community. Social media is a massive growth area for online marketers and one of which has potential to offer highly targeted advertising to specialized social groups. The transition of Theater Koma's marketing technique from offline to the digital world by utilizing social media needs to be developed because it is important in effort to regenerate the audience. This scientific was made written by conducting field observations during production process of the "Gemintang" show from mid-April 2018 to July 15 2018. This research aims to let us know the marketing techniques which have been applied to production of "Gemintang" show. This research concludes that awareness of the need for the existence of an art group is not only proven by work productivity itself, but how the work could be recognized and accepted by various segments of society which current entered the digital era.
\end{abstract}

Keywords: Digital Marketing, Social Media, Gemintang Performance, Koma Theater.

\section{INTRODUCTION}

These days performing arts and other art groups are often faced with problems in marketing their products. This is because there are difficulties in finding out which strategies will be used in marketing these products. In this case, one of the performing arts communities that markets its products using a marketing strategy is the koma theater.

Theater Koma is a theater group which has been active in production since 1977. For 43 years Theater Koma has always been actively producing. Their shows always have a place in the hearts of the audience and all walks of life. It is undeniable that at the age of 43, Theater Koma already has a loyal audience who will come to buy tickets to watch any programs served there.

According to recent market phenomena, various performing arts communities create marketing strategies therefore in the future they could remain competitive in the world of 
creative industries, especially in Indonesia. The performing arts community in Indonesia determines its existence by looking at market segmentation (segmenting), target market (targeting) and positioning strategies (positioning).

Social media is a massive growth area for online marketers and one of which has potential to offer highly targeted advertise to specialized social groups based on pro information they offered through popular sites like Facebook, Twitter, Instagram and so on. Based on these exposure to statistical data, it is known that in 2016, Facebook became a website-based social media which had the highest active access in Indonesia.

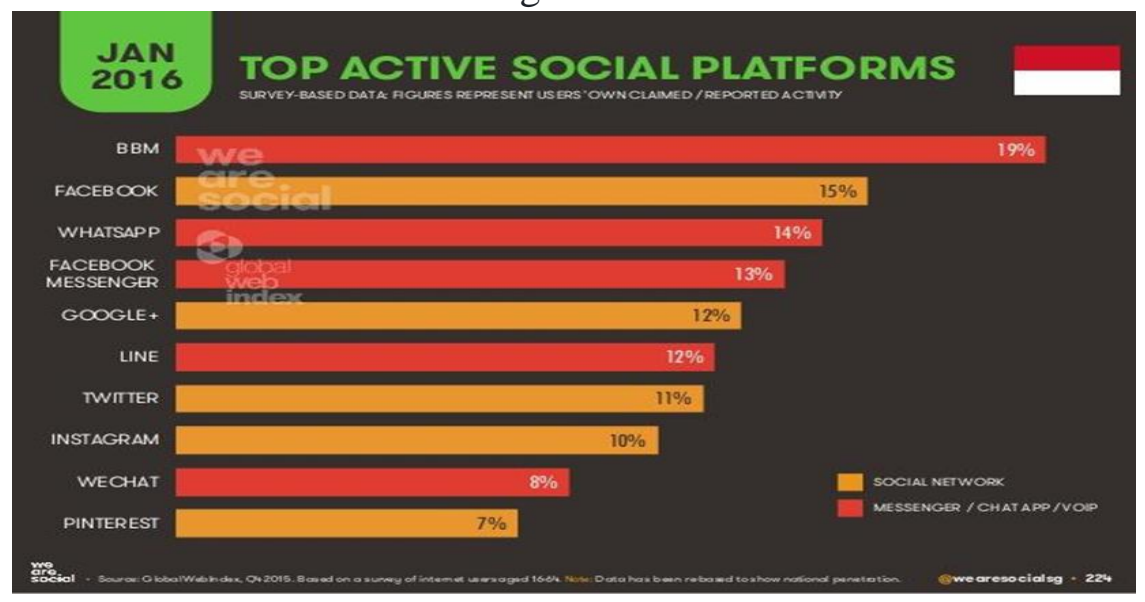

Figure 1. Social Media Platforms in Indonesia

Source: We Are Social

The "Gemintang" show is the 153rd production of a new script by director N. Riantiarno, which is the first show at Theater Koma. The "Gemintang" show tells about the corrupt family life which is chaotic, about the youngest son from millennial generation who is intelligent, critical, but loves to hang out and clubbing who did not want to live under the shadow of his corrupt father, then wraps it with story about a love relationship between each stars between humans and other planetary creatures. Therefore, it is very necessary to play an important role in production management for the smooth running of a stage and the success of an art group. Performing arts production requires proper marketing techniques so it could be accepted by the target community. This marketing technique should be dynamic because the nature and interests from targeted communities will always change according to the era.

This needs to be a detail concern because marketing itself is exists not only to maintain the existence and its survive, but also acts as a means of improving the performances quality to be the best among similar groups or communities. Marketing technique in question is a comprehensive integrated planning related to the strength and ability of Koma Theater in facing market changes, especially in 2018.

This scientific essay was made by conducting field observations on the production process of "Gemintang" show during mid-April 2018 to 15 July 2018. The author has observed that the development of marketing techniques which were carried out by Koma Theater thats now based an internet minded society. Koma theater management marketing is oriented towards the artistic process. Koma Theater Market was then created through a creative process of forming artistic-aesthetic-ethical concepts and their manifestations. 


\section{LITERATURE REVIEW}

\section{Koma Theater}

Theater was born because of the need to create another aesthetic sense, such as the desire to convey something. Staging is the answer to the desire to convey something that was born because of needs which are more cultural in nature. The style of Masres Ketoprak Lenong, Opera Bangsawan and Komedie Stamboel, which has been developed and eventually became a Koma Theater style.

\section{Koma Theater Performance Marketing}

Basically, the marketing of the show was done so all the art that being staged is successful in attracts those large audiences to each production. Koma theater has its own way of managing the marketing of its shows, starting from offline marketing until now it has started to penetrate the digital world.

\section{Marketing}

Kotler (2007:5) stated that marketing is a business function that identifies current unmet wants and needs and measures how big the market will be served, determines the target markets which best served by the organization, and find out those various products, services and programs that has good to serve those market.

\section{Digital Marketing}

The development of internet technology in recent decades has created a new effective marketing communication medium, which commonly known as digital marketing. Digital marketing is a marketing practice which uses digital distribution channels to reach consumers in a way that is relevant, personal and cost-effective (Satyo, 2009). Marketing activities will be carried out intensively using computer media, starting from product offering, payment and delivery.

\section{Social Media Marketing}

Marketing through social media allows building social relationships which more personal and dynamic than traditional marketing strategies. Social media marketing is the newest addition to the marketing world where it used to establish communication on unified marketing plans. Integrated communication is a principle of organizations that connected to their target market. Integrated marketing communications include promotion, advertising, personal selling, public relations, direct marketing and sales promotion (Glynn and David, 2009).

\section{Gemintang Show}

The "Gemintang" drama is the 153rd production of a new script by director $\mathrm{N}$. Riantiarno, which is the first show of Koma Theater. The "Gemintang" show tells about the corrupt family life that is chaotic, about the youngest son of millennial generation who is intelligent, critical, but loves to hang out and clubbing who did not want to live under the 
shadow of his corrupt father, then it wraps with a story about a love relationship between each stars between humans and other planetary creatures.

\section{RESEARCH METHODS}

This research includes a qualitative descriptive research way to examine the condition of natural objects with the aim of explaining those phenomena deeply through digging up the data collection. These research methods used a case study by various data sources. Primary data was obtained by conducting interviews with informants related to the performing art "Gemintang" in Koma Theater, while secondary data was obtained from books, data from the internet and other data sources. This research used data reduction as a technique in analyzing the data served then its drawn as conclusions and solutions to the research questions.

\section{RESULTS AND DISCUSSION \\ Research Findings}

Koma Theater conducts promotional activities through distributing posters and flyers through wall magazines for schools, universities, coffee shops and several other strategic places. Furthermore, several promotional activities have been carried out by the organizers, including via Koma Theater Website, namely www.teaterkoma.org, and online ticket sales through Loket.com, Koma theater also provides offline locations at the venue H-5 of the show because the ticket sales team for the Gemintang show is also a player in that show. Koma Theater also advertises its performances via SMS manually and Broadcast WhatsApp chat which is managed by the children of the two Riantiarno Families.

These days, new web technologies make it easier for anyone to create and most importantly distribute to their own content. By these development of technology, Koma theater has also made breakthroughs in the form of marketing through social media, Facebook, Twitter and Instagram. Moreover, Koma theater also posted advertisements regarding to the Gemintang performance in collaboration with the Bakti Budaya Djarum Foundation website www.Indonesiakaya.com with several sponsors listed in the ad, such as BCA, PAC, CANON, TIKI, EPSON and Blibli.com.

Based on Dika's statement, Koma theater's website Traffic began to get busy when people wanted to buy tickets when advertisements related to the upcoming performances were published both on social media as well as in SMS and email. Besides that, Dika added that merchandise sales in the form of Koma Theater's shirts, within 10 performance days per day, would be able to sell up to 20 pieces of it. According to the data served, it shows that there is considerable enthusiasm from the audience to the Gemintang show that organized by Koma Theater. During these 10 days of performances held by Koma theater, the average number of tickets sold was quite a lot. However, when the show was held, it was seen that the audience present did not match the records with the number of tickets that had been sold. 
Table 1. Gemintang Audience Report during June - July 2018

\begin{tabular}{|c|c|c|c|c|}
\hline Day and Date & Days to- & $\begin{array}{c}\text { Tickets } \\
\text { Sold }\end{array}$ & $\begin{array}{c}\text { Number of } \\
\text { Viewers }\end{array}$ & $\begin{array}{c}\text { Percentage of } \\
\text { Attendance }\end{array}$ \\
\hline Friday, June, 29 $^{\text {th }} 2018$ & 1 & 504 & 441 & $87.50 \%$ \\
\hline Saturday, June, 30 $^{\text {th }} 2018$ & 2 & 482 & 453 & $93.98 \%$ \\
\hline Sunday, July, 1 $1^{\text {st }} 2018$ & 3 & 465 & 434 & $93.33 \%$ \\
\hline Monday, July, 2 $^{\text {nd }} 2018$ & 4 & 799 & 754 & $94.37 \%$ \\
\hline Tuesday, July, 3 $^{\text {th }} 2018$ & 5 & $750 *$ & 464 & $61.87 \%$ \\
\hline Wednesday, July, 4 $^{\text {th }} 2018$ & 6 & 528 & 502 & $95.08 \%$ \\
\hline Thursday, July, 5 $^{\text {th }} 2018$ & 7 & 488 & 446 & $91.39 \%$ \\
\hline Friday, July, 6 $^{\text {th }} 2018$ & 8 & 494 & 447 & $90.49 \%$ \\
\hline Saturday, July, $7^{\text {th }} 2018$ & 9 & 421 & 377 & $89.55 \%$ \\
\hline Sunday, July, 8 $8^{\text {th }} 2018$ & 10 & 496 & 453 & $91.33 \%$ \\
\hline Total & - & $\mathbf{2 , 4 2 7}$ & $\mathbf{2 , 2 2 5}$ & \\
\hline
\end{tabular}

Source: Koma Theater ticket team data, 2018

The Gemintang performance itself was filled with young members of Koma theater, who are mostly millennials and very familiar with the use of social media. The young members of the Koma Theater who are involved in Gemintang performance each have their own content to be posted in their respective social media. Koma theater itself captures several moments during the Gemintang performance. Other than that, the writings or articles which appear in print media reports such as newspapers related to its show on the special performance date were also used as a strategy by Koma Theater to disseminate news about their performances so it would attracts other potential viewers who wish to watching, then could increase the number of viewers every day as long as the Gemintang performance was helds.

Based on the writer's observation, it is true that the audience who attended the Koma Theater show included an audience who was a new audience of the younger generation. Although the older generation audience still dominates the vibes. The author asked one of the spectators who was randomly selected, that most of the old generation of Koma theater viewers knew about the Gemintang performance because of information from SMS and WhatsApp. There were also those who knew about these Gemintang performances from their children who are followers of Koma Theater's Instagram.

The change in the sale of Koma theater tickets from offline to online and turned out to be a polemic for the old generation of Koma theater viewers. One of the spectators who wrote the interview argued that he believed more in purchasing tickets offline, which is by phone to Sanggar Teater Koma or by coming to Sanggar Teater Koma in person, like its previous way. It turns out that many people did not understand how to order the tickets online and at the end some of them feel lazy to buy or ask their children to help with ordering tickets for Koma Theater.

Based on the data that authors gained, it could be seen that the percentage of Instagram visitors based on gender was women, which is by $52 \%$, while for men only $48 \%$. Besides that, the number of followers is more active at night, such as at 6 and 9 at night or 18.00 and 21.00. 
Furthermore, based on the location of the follower, was dominated by followers who live in Jakarta area. Then based on their age, they are dominated by followers with age ranges between 18-24 years and 25-34 years.
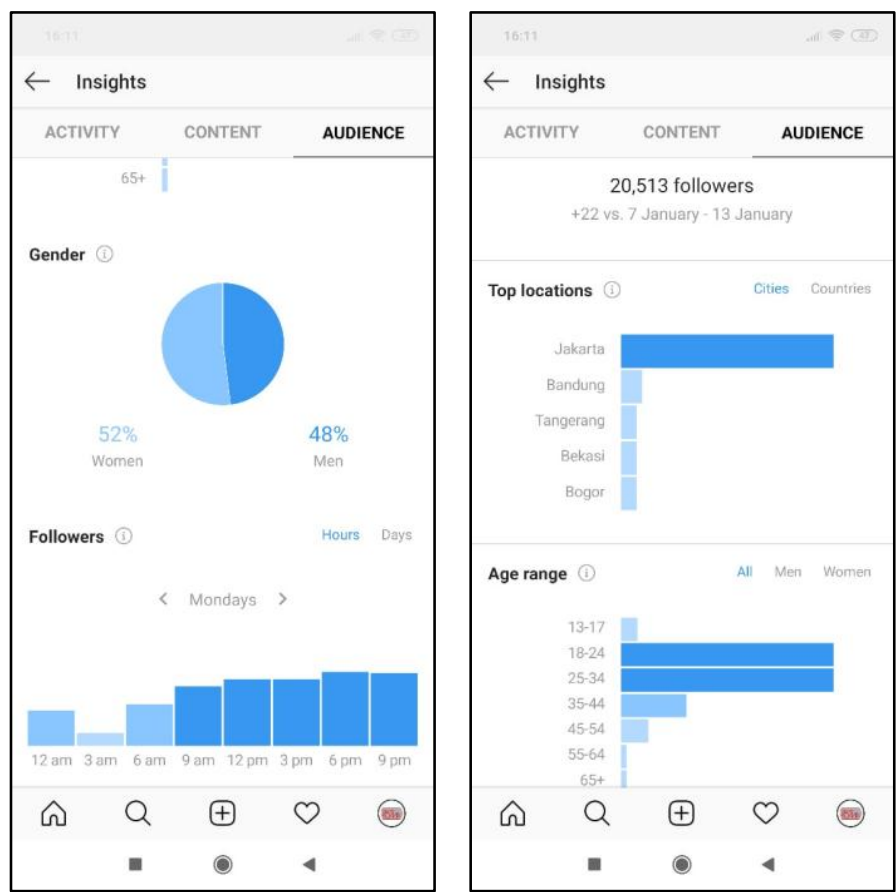

Figure 2. Audience of Koma Theater's Instagram Account

Source: Koma Theater's Instagram Insight, 2018

The thing that is quite unfortunate is that the author only gets data in the form of Insights from Teater Koma's Instagram. Though Teater Koma also has a fanpage on Facebook and Twitter. These two social media actually also have insight features, just like the Instagram business account. However, Dika believes that the insights from Twitter and Facebook cannot be used as reference data for this writing, because posts on Instagram can be forwarded to the Twitter account and Facebook fanpage at the same time.

\section{Analysis}

\section{Segmentation of Koma Theater Audience}

Adopting these "Four Segments of the Green Market" from Philip Kotler's Marketing 3.0 book, it is important to know that the theater market for koma theater is not homogeneous. Based on this theory, Koma theater were also has four audience segmentations that could be grouped specifically. 
Table 2. Four Segments of Koma Theater Audience

\begin{tabular}{|c|c|c|c|c|}
\hline \multicolumn{5}{|c|}{ AUDIENCE SEGMENTATION } \\
\hline & Trendsetter & Value-Seeker & $\begin{array}{c}\text { Standard } \\
\text { Matcher }\end{array}$ & $\begin{array}{c}\text { Cautions } \\
\text { Buyer }\end{array}$ \\
\hline Profile & $\begin{array}{c}\text { Koma theater } \\
\text { loyal } \\
\text { audience } \\
\text { Theater } \\
\text { Lovers }\end{array}$ & $\begin{array}{c}\text { People who } \\
\text { believe that } \\
\text { they get new } \\
\text { knowledge and } \\
\text { values after } \\
\text { watching at } \\
\text { koma theater }\end{array}$ & $\begin{array}{c}\text { People who } \\
\text { stick with } \\
\text { certain } \\
\text { standard of } \\
\text { Koma Theater } \\
\text { performance }\end{array}$ & $\begin{array}{c}\text { People who are } \\
\text { not interested } \\
\text { in theater }\end{array}$ \\
$\begin{array}{c}\text { Special } \\
\text { Treatment } \\
\text { Determination } \\
\text { / Service }\end{array}$ & $\begin{array}{c}\text { Give a show } \\
\text { which different } \\
\text { from other } \\
\text { theaters }\end{array}$ & $\begin{array}{c}\text { Provide more } \\
\text { values and } \\
\text { knowledge }\end{array}$ & $\begin{array}{c}\text { Providing } \\
\text { general } \\
\text { information } \\
\text { about the } \\
\text { shows } \\
\text { produced }\end{array}$ & Create demand \\
\hline
\end{tabular}

\section{An Influence of the Digital Subculture}

\section{Young People as Potential Group for Information Sharing}

The role of young people in influencing the market is very large. Young people act as early adopters, trendsetters, and game changers. Referring to the conclusion that young people are the key to mind sharing. If a brand wants to influence the minds of mainstream consumers, convincing young people is the first step that it must take. In this case, the Gemintang performance by Koma Theater then convinces and invites young people to participate in holding that an art show so it could invite, involve many parties, and bring in many enthusiasts to participate both in organizing the show and watching it together.

\section{Netizens as Potential Groups to Create Demand}

Netizens, also known as people on the internet, are considered as democratic societies because they are associated with the fastest growth of the internet. Netizens are social connectors, they talk to each other, and information flows like what they talk about. There are many ways to connect online on the internet. The most popular are SNS (Social Networking Services) and instant messaging apps such as Facebook, WhatsApp, QQ, Instagram, Twitter, Tumblr and LinkedIn. Netizens are also expressive evangelists. By not revealing his real identity, internet users could become very aggressive somehow in expressing their opinions. Netizens who are in very deep love (big fans) for a product or service would be more suitable to get the title of brand evangelists. Netizens are also content contributors. They are called internet citizens' for a reason. Like people who contribute to their country, they contribute to the development of the internet. The work of netizens makes life easier for other internet users. With ratings and reviews on the internet, other users could easily find the best available options. With new content being created every second, the internet is becoming richer and 
more useful, that will benefit its users, and attract non-users to start using the internet. The growth in netizen popularity is as good as the result of the internet itself. With an exponential growth that starts from emotional and mutually beneficial relationships, the community of netizens is the key to developing a brand's Heart Share.

\section{The use of Social Media as For Marketing}

Koma Theater should know how to collaborate with the audience. Collaboration could occur when the marketing department listens to the audience and understands what the audience wants and it does conversely. Unfortunately, as long as Koma theater has a social media account, they did not partnered with any social media influencers to collaborate and create a new generation of audiences, in this case young people. Collaboration with social media influences is more profitable when the audience plays a major key in creating results through performances and services. Besides it helps the development of the show, Netizen reactions will also contribute to creating ideas for advertising.

Marketing moves slowly. Initially, marketing was transaction-oriented and focused on sales alone. Furthermore, marketing is relationship-oriented, focusing on how to keep consumers coming back and buying more. Then marketing changes into inviting consumers to participate in the company's product development and communications. In this case, Koma theater also needed to invite the audience to participate in developing the show and interacted with another audience.

\section{Consumers as Marketers for Other Consumers}

Through social media, a show created by Koma theater and has been watched by the audience will cause a reaction conveyed by the audience through social media to the show itself. From there, an assessment or review will emerge that could be used as a reference for potential viewers and other viewers from Koma Theater performance. Offline viewers will ask questions to other viewers as a review assessment that was given to the show itself. Furthermore, online viewers could give their own reviews through various social media related to Koma Theater.

\section{Content Marketing}

In fact, social media provides opportunities for marketers to communicate directly with their consumers. And Social media has the possibility to have more interactive conversations. With the existence of two-way communication to the consumers, it will be more effective and more cost efficient. In order to attract consumers, sometimes marketers need to create a content that is not directly related to brand value or increases its sales volume, but increases its consumers.

Basically, content marketing includes content production and content distribution. Effective content marketing requires marketers who are creating content should be original or from external sources. In this case, the Koma Theater aims to sell out tickets for the Gemintang show on every show played. Once the goals have been determined, the audience mapping should need to be done as well. Based on the four predetermined segments, Koma Theater can 
find out what kind of marketing content should be made and create a timeline whenever such content is published on social media. This content should be designed to fit with the target audience market, so it would be straight on target. For example, when Koma Theater made an early bird ticket promo with $20 \%$ discount for 5 days, which was published 10 days earlier before the promo date. The early bird ticket promo design should be made in shades of galaxy purple, representing the show's title; "Gemintang"

Content distribution needs to be considered. In which social media do they belong to the Koma Theater which has the most active followers? At what time are Koma Theater followers active on social media? This could be answered if Koma Theater pays attention to the Insight feature on each of its social media accounts. Many marketers changed their system from advertising to content marketing. Changing a mindset is necessary. Marketers should be able to spread useful and valuable content on their consumers. In developing these marketing content, marketers often focus on content production and content distribution. How marketers plan to utilize content assets and interact with customers is also of great concern. In this case, according to the author's analysis, Koma Theater has only created one-way content. There has not been any significant interaction with their followers. Unlike the content created by young members of Koma Theater, young members of Teater Koma, Sekar Dewantari made content on the Instagram Stories with features in the form of short videos about why you should watch Gemintang performances. In that video, Sekar invited her Instagram followers to watch Gemintang and there was a dialogue in it.

As an organizer and marketer, Koma Theater needs to evaluate the impact from published content on its social media accounts in more detail. Because according to the author's observations and analysis, based on interviews with Dika from Koma Theater's marketing, twenty thousands of Koma Theater followers are deemed sufficient if given one-way content as has been done by Koma Theater

Furthermore, the author also analyzes the role of young members on Koma theater in creating a content which more two-way in style and needs to be published more and more to embrace the new generation of audience candidates for Koma Theater. On top of that, good marketing content requires preparation of the right production and distribution system.

\section{CONCLUSION AND SUGGESTION Conclusion}

Based on these research results which the author has conducted, these research conclusions could be drawn as follows:

1) Before the existence of social media as a media promotion for Koma theater, which attracted the attention and interest of potential viewers using offline marketing, such as through advertising with posters, flyers and billboards. Besides that, Koma theater also carried out promotions through the creation of articles in Kompas newspaper news column. At the time of the "Gemintang" show started they were still promoting these media. Koma theater also promotes its performances by SMS manually and Broadcast WhatsApp chat. Then, since its found, they started to consider changing its marketing based to social media, such as by creating its official Facebook and Twitter accounts in 2009. Besides, in the same 
year, 2009, Koma theater just got its own official website. As for the Instagram account, Koma theater created this account on April 13, 2015.

2) By these increasingly sophisticated development of the era, Koma theater, which previously only relied on offline media in promoting its shows and now has begun to following technological developments by trying to changes its marketing strategy, such as by using social media facilities which have developed and widely used by the wider community, especially by millennials. Specifically, the Koma Theater website has also been used as a medium for selling tickets for shows online.

3) Apart from using manual SMS and WhatsApp chat broadcasts, Koma Theater also used several social media platforms such as Instagram, Facebook, Twitter and the Koma Theater Website in introducing and marketing them to the wider community.

4) Traffic website of Koma Theater would begin to get busy when people wanted to buy tickets when advertisements about the upcoming performances were published both on social media and SMS also email. In addition, the merchandise sales in the form of Koma theater's shirts could sell up to 20 pieces of shirts per day. Since 2016, Koma theater has had approximately 10,000 spectators. Those data are in the form of name, address, email and cell phone number. For the Gemintang show itself, there are 797 seats per day for sale. This is considered as enthusiasm from the audience on the Gemintang show which was organized by Koma Theater. Beside that, on the $\mathrm{X}$ day of the performance there are articles that would be written in news related to the "Gemintang" performance, that could increase the number of viewers each day during the Gemilang performance activities. This explained how effective the utility of social media is as a medium for promotion. However, based on interview results, it described that most of the old generation of Koma theater viewers knew about Gemintang performances because of this information via SMS and WhatsApp. There were also people who knew about these Gemintang performances from their children who meant to be followers of Koma theater's Instagram. The sales method changed from offline to online has turned out to be a polemic for its old generation viewers. Those interviewees' results revealed that they had more confidence in purchasing tickets offline, which is by phone to Sanggar Teater Koma or by coming to Sanggar Teater Koma in person, like those previous ticket sales. This results are less efficient in the use of social media.

5) Koma theater has four audience segmentations which could be grouped specifically, such as Trendsetter, Value-seeker, Standard Matchers and Cautious Buyers. The grouping of audiences into four segments is important in order to support the survival of Koma theater. The main targets is hoping that Koma theater will continue to have an audience so it would remain productive.

\section{Suggestion}

After done with conducting the research, then the authors has proposed some of suggestions or input related to Koma Theater Marketing Strategy, such as following sentences:

1) Koma theater needs to evaluate and reformulate its strategy in attracting the audience interest. Even though social media is very hyped and has generally been used as a medium of disseminating information in various fields, especially business. However, it turns out 
that there are still some people who do not take advantage of it personally. So, the koma Theater needs to develop those marketing strategies both offline and online. So, both active and passive social media users could be reached by the information that they want to convey.

2) As for active social media users, Koma Theater needs to use several information that is obtained from several supporting applications such as Instagram Insight to monitor its developments and disseminate information about Koma Theater. So, it could be considered as more precisely in implementing the strategy that has been decided

1) And for passive social media users, it is good if The Koma Theater would be more active in socializing and more aware in providing such information to the wider community.

\section{REFERENCES}

Atmoko, Dwi Bambang. 2012. Instagram Handbook Tips Fotografi Ponsel. Jakarta: Media Kita.

Curran, J \& Lennon, R. 2011. Social Network and Old User: An Examination Attitudes and Usage Intention. (http://www.businessjournalz.org/CMR_2013apr.pdf).

Gurnelius, Susan. 2011. 30-minute Social Media Marketing. United States: McGraw-Hill Companies.

Glynn, W. mangold; David, J Faulds. 2009. Social Media: The New Hybrid Element of The Promotion Mix, Busimess 52. 357-365.

Karjaluoto. 2008. A Prime in Social Media: Examining of Phenomenon, its Relevance, Promise and Risks. (http://www.smashlab.com/media/white-papers/a-primer-in-socialmedia)

Kotler, Philip. 2007. Manajemen Pemasaran. Jakarta: PT Indeks.

Kotler, Philip. dkk. 2010. Marketing 3.0: From Products to Customers to the Human Spirit. New Jersey: John Wiley \& Sons, Inc.

Kotler, Philip. 2011. Manajemen Pemasaran di Indonesia: Analisis, Perencanaan, Implementasi dan Pengendalian. Jakarta; Salemba Empat.

Kotler, Philip. dkk. 2017. Marketing 4.0: Moving from Traditional to Digital. New Jersey: John Wiley \& Sons, Inc.

Moleong J.Lexy. 2005. Metodologi Penelitian Kualitatif. Bandung: Remaja Rosdakarya

Sanjaya, Ridwan dan Tarigan Josua. 2009. Creative Digital Marketing. Jakarta: PT Elex Media Komputindo

Satyo Fatwan. 2009. Intellectual Capital. Jakarta: Gramedia Pustaka Utama

Situmorang, Syafrizal Helmi dan Muslich Lutfi. 2011. Analisis Data untuk Riset Manajemen dan Bisnis, Edisi 2, USU Press, Medan.

Thoyibi, L. 2010. Psikologi social media. (http://komunikasi-indonesia.org)

Tracy, LaQuey. 1997. Sahabat Internet. Bandung: ITB.

Wenats, AG Eka. 2012. Integrated Marketing Communications Succes Story. Jakarta: PT. gramedia Pustaka Utama.

Zarella, D. 2010. The Social Marketing Book. Jakarta: PT. Serambi Ilmu Semesta Anggita IKAPI. 